Int. J. Odontostomat.,

10(1):113-118, 2016.

\title{
Epithelial Odontogenic Tumors: Analysis of 156 Cases in a Brazilian Population
}

\author{
Tumores Odontogénicos Epiteliales: Análisis de 156 Casos en una Población Brasileña
}

\author{
Rayssa Mendes Cavalcante*; Moan Jéfter Fernandes Costa*; \\ Nelmara Sousa e Silva*; ${ }^{*}$ Lélia Batista de Souza ${ }^{* * *}$ \& Pedro Paulo de Andrade Santos ${ }^{\star * * *}$
}

CAVALCANTE, R. M.; COSTA, M. J. F.; SOUSA E SILVA, N.; DE SOUZA, L. B. \& SANTOS, P. P. A. Epithelial odontogenic tumors: analysis of 156 cases in a Brazilian population. Int. J. Odontostomat., 10(1):113-118, 2016.

\begin{abstract}
The objective of this study was to determine the distribution of epithelial odontogenic tumors diagnosed histologically in a period of 41 years in a Brazilian population according to age, gender, site affected and compare these data with previously reported studies from other countries. Data of epithelial odontogenic tumors diagnosed were collected from the files of the Oral Pathology Laboratory of Federal University of Rio Grande do Norte, Natal, RN, Brazil, and entered in a standardized form for later comparisons. Clini-cal features obtained from the patient records and microscope slides were reviewed according to the 1992 World Health Organization classification. A total 156 epithelial odontogenic tumor were reported. Of these, all of them were benign. Ameloblastoma was the most frequent type (85.9 \%), followed by adenomatoid odontogenic tumor (10.9\%) and calcifying epithelial odontogenic tumor (3.2\%). The mean age of the patients was 38 years, with a wide range (11-80 years). The posterior region of mandible was the anatomic site most frequently affected by this disease, and no significant differences were found between sexes in the diagnosis of odontogenic tumors. A marked geographic variation in the relative incidences of various epithelial odontogenic tumors was found. It was particularly notable in ameloblastomas and adenomatoid odontogenic tumors, with the incidences observed in the present study being similar, sometimes different to earlier studies in others parts of the world.
\end{abstract}

KEY WORDS: odontogenic tumor, ameloblastoma, adenomatoid odontogenic tumor, calcifying epithelial odontogenic tumor.

\section{INTRODUCTION}

Odontogenic tumors (OTs) constitute a heterogeneous group of lesions with diverse histopathologic features and clinical manifestations. The spectrum of biologic behavior of these lesions includes hamartomatous proliferations, benign nonaggressive and aggressive tumors, and malignant tumors. Because there is a diversity of lesions that can arise from the odontogenic tissues, several classification schemes have been published in an attempt to define their diagnostic criteria (Buchner et al., 2006).

Epithelial odontogenic tumors (EOTs) are composed only by odontogenic epithelium with mature fibrous stroma but not with ectomesenchyme (Tawfik \& Zyada, 2010), in this group of odontogenic tumors, ameloblastoma is the most important and more common of them (Tawfik \& Zyada; Adebayo et al., 2005; Simon et al., 2005; Sriram \& Shetty, 2008; Luo \& Li, 2009).

Knowledge of prevalence of various types of OTs and their clinical characteristics can be extremely valuable both for pathologists and clinicians when developing differential diagnosis, and may lead to clues concerning the causes of these lesions (Luo \& $\mathrm{Li}$ ). Reports on the relative frequency of OTs from different parts of the world, covering different ethnic

Undergraduate Student, PIBIC/CNPq, Dentistry College, Federal University of Campina Grande- UFCG, Patos, PB, Brazil.

** Undergraduate Student, PIVIC/CNPq, Dentistry College, Federal University of Campina Grande- UFCG, Patos, PB, Brazil.

${ }^{* * *}$ DDS, PhD, Oral Pathology Post-Graduate Professor, Dentistry Department, Federal University of Rio Grande do Norte, Natal, Brazil.

.*** DDS, PhD, Oral Pathology, General Pathology, Histology and Embriology Professor, Federal University of Campina Grande, Health Center and Rural Tecnolog, Patos, Brazil. 
groups have been documented (Buchner et al.; Tawfik \& Zyada; Adebayo et al.; Simon et al., 2002, 2005; Ogunsalu, 2003; Sriram \& Shetty; Luo \& Li; Tamme et al., 2004; Ochsenius et al., 2006; Olgac et al., 2006; Jing et al., 2007; Okada et al., 2007).

Because of the diversity of lesions that can arise from the odontogenic tissues, several classification schemes have been published in an attempt to define their diagnostic criteria and biologic behavior. At present, most investigations cite the World Health Organization Classification of Odontogenic Tumours (Mosqueda-Taylor et al., 1997).

The aim of this study was to establish the relative frequency of various histological types of epithelial odontogenic tumors (EOTs) at the Oral Pathology Laboratory of Federal University of Rio Grande do Norte, Natal, RN, Brazil, in 41 years. We also attempted to compare our findings with those reported from other parts of the world.

\section{MATERIAL AND METHOD}

A total of 11.378 accessioned cases were retrieved from the files of our department during the period of 40 years. All cases coded as EOTs were reevaluated and the diagnosis in each case it was confirmed or modified according to the World Health Organization histologic classification of 1992. Bonerelated lesions and other tumors were not included. In the case of recurrent tumors, the histology of the original and the recurrent tumors were compared and they were considered as one individual case. The clinical details, including age and sex of the patient, duration, location and extent of the lesion, were collected. Available radiographs of some cases were also referred to if it was necessary for confirming the diagnosis. The maxillary and mandibular lesions were divided into 3 categories based on its extent. Class 1 consisted of lesions limited to the anterior segment of maxilla or mandible (distal aspect of right canine to distal aspect of left canine). Class 2 consisted of lesions limited to the posterior segment of maxilla or mandible (from mesial aspect of first premolar distally). Class 3 consisted of lesions that extended into anterior and posterior segments of the maxilla or mandible. The study was approved by the Ethics Committee of UFRN (protocol 027-10), Natal, RN, Brazil.

\section{RESULTS}

A total of 156 cases of EOTs were confirmed. The most frequent EOT was ameloblastoma $(85.9 \%)$, followed by adenomatoid odontogenic tumor (10.9\%) and calcifying epithelial odontogenic tumor (3.2\%). Regarding sex and age, $43.59 \%$ of all of the EOTs occurred in males and $56.41 \%$ in females (Table I). The peak age of incidence was the second to fifth decades of life. Patients' age ranged from 11 to 80 years, with a mean age of 38 years.

In general, the mandible was the most frequently affected jaw, corresponding to $85.9 \%$ of the cases, and the maxilla was affected in $14.1 \%$ of the cases. The most frequently affected area in mandible was the posterior region (Class 2) with $79.9 \%$, followed by anterior region (Class 1 ) with $11.9 \%$, and anterior-posterior region (Class 3 ) with $2.2 \%$. In maxilla the most affected region was the anterior (Class 1) with $8.3 \%$ followed by the posterior region (Class 2 ) with $5.1 \%$, and in just one case this information was not available corresponding to $0.6 \%$ (Table II). Most of EOTs was asymptomatic in 87 cases (55.8\%), symptomatic in 40 cases $(25.6 \%)$ and this information was not available in 29 cases $(18.6 \%)$ (Table III). For histopathological analysis, excisional biopsy was performed in $37.2 \%$, followed by incisional biopsy in $34 \%$ and in $28.8 \%$ this information was not available. The recorded duration in 156 EOTs ranged from 0 day in lesions detected by dental check-up for other treatment, to 33 years in a case of long-standing untreated ameloblastoma (Table III).

One-hundred thirty four cases of ameloblastomas (AMEs) were verified in this study, and these cases accounted for $85.9 \%$ of all of the epithelial tumors. The cases occurred in 74 females and 60 males (Table I), and the third and forth decades were the most affected. The youngest patient was 11 years old and the oldest was 80 years old (Table I). Most of AMEs were in mandible in 127 cases (94.8\%) and the posterior region was affected in 107 cases (79.9\%) (Table II). Seventyseven cases of AMEs were asymptomatic (57.5\%), Thirty-six cases was symptomatic $(26.9 \%)$, and in twenty-one cases $(15.7 \%)$ this information was not available (Table III). The longest duration without treatment of AME was 33 years (Table III), and an incisional biopsy was performed in $37.3 \%$ of AMEs.

Seventeen cases were diagnosed as adenomatoid odontogenic tumor (AOT), which corres- 
ponded to the second most frequent tumor, accounting for $10.9 \%$ of all cases of EOTs in this study. The cases occurred in 13 females and 4 males (Table I), and the first and second decades were the most affected. The youngest patient was 12 years old and the oldest was 45 years old (Table I). Most of AOTs were in maxilla in 12 cases $(70.6 \%)$ and the anterior region was involved in 10 cases $(58.8 \%$ ) (Table II). Seven cases of AOTs were asymptomatic $(41.2 \%), 3$ cases were symptomatic $(17.6 \%)$ and in seven cases $(41.2 \%)$ this information was not available (Table III). The longest duration without treatment of TOA was 7 years (Table III), and an excisional biopsy was performed in $52.9 \%$.
Just five cases were diagnosed as calcifying epithelial odontogenic tumor (CEOT) were found, corresponding to $3.2 \%$ of all EOTs in this study (Table II). The cases occurred in 4 males and 1 female (Table I), and the fifth and sixth decades were the most affected. The youngest patient was 18 years old and the oldest was 71 years old (Table I). Most of CEOTs were in maxilla in 3 cases $(60 \%)$ and the posterior region was involved in 2 cases (40\%) (Table II). Three cases of CEOTs were asymptomatic (60\%), 1 case was symptomatic $(20 \%)$ and in one case $(20 \%)$ this information was not available (Table III). The duration without treatment wasn't specified (Table III) and an incisional biopsy was performed in $40 \%$ of CEOTs.

Table I. Frequency, age, and sex distribution of epithelial odontogenic tumors (EOTs).

\begin{tabular}{lccccccc}
\hline \multirow{2}{*}{ Type of Lesion } & \multicolumn{2}{c}{ Female } & \multicolumn{2}{c}{ Male } & \multicolumn{2}{c}{ Total } & \multirow{2}{*}{ Age range $(\boldsymbol{y})$} \\
\cline { 2 - 7 } & $\boldsymbol{n}$ & $\boldsymbol{\%}$ & $\boldsymbol{n}$ & $\boldsymbol{\%}$ & $\boldsymbol{n}$ & $\%$ & \\
\hline Ameloblastoma & 74 & 55.22 & 60 & 44.78 & 134 & 85.9 & $11-80$ \\
AOT & 13 & 76.47 & 4 & 23.53 & 17 & 10.9 & $12-45$ \\
CEOT & 1 & 20 & 4 & 80 & 5 & 3.2 & $18-71$ \\
Total & 88 & 56.41 & 68 & 43.59 & 156 & 100 & $11-80$ \\
\hline
\end{tabular}

AOT= Adenomatoid Odontogenic Tumor; CEOT= calcifying epithelial odontogenic tumor; $y=$ year.

Table II. Distribution of 144 of epithelial odontogenic tumors (EOTs) by location.

\begin{tabular}{|c|c|c|c|c|c|c|c|}
\hline \multirow{3}{*}{ Type of lesion } & \multirow{3}{*}{$\begin{array}{c}n \text { of cases } \\
(\%)\end{array}$} & \multicolumn{2}{|c|}{ Maxilla } & \multicolumn{3}{|c|}{ Mandible } & \multirow{3}{*}{$\begin{array}{l}N S \\
(\%)\end{array}$} \\
\hline & & Anterior (\%) & Posterior (\%) & Anterior (\%) & Posterior (\%) & $\begin{array}{l}\text { Anterior and } \\
\text { Posterior (\%) }\end{array}$ & \\
\hline & & Class 1 & Class 2 & Class 1 & Class 2 & Class 3 & \\
\hline Ameloblastoma & $134(85.9)$ & $2(1.5)$ & $4(3.0)$ & $16(11.9)$ & $107(79.9)$ & $3(2.2)$ & $1(0.7)$ \\
\hline АOT & $17(10.9)$ & $10(58.8)$ & $2(11.8)$ & $5(29.4)$ & $1(5.9)$ & $0(0.0)$ & $0(0.0)$ \\
\hline CEOT & $5(3.2)$ & $1(20)$ & $2(40)$ & $1(20)$ & $1(20)$ & $0(0.0)$ & $0(0.0)$ \\
\hline Total & $156(100)$ & $13(8.3)$ & $8(5.1)$ & $22(14.1)$ & 109 (69.9) & $3(1.9)$ & $1(0.6)$ \\
\hline
\end{tabular}

NS= Not specified; AOT= Adenomatoid Odontogenic Tumor; CEOT= Calcifying epithelial odontogenic tumor.

Table III Clinical feature and longest duration of symptoms

\begin{tabular}{lcccr}
\hline \multirow{2}{*}{ Type of lesion } & \multicolumn{3}{c}{ Symptom } & Longest \\
\cline { 2 - 4 } & Asymptomatic (\%) & Symptomatic (\%) & NS (\%) & Duration \\
\hline Ameloblastoma & $77(57.5)$ & $36(26.9)$ & $21(15.7)$ & 33 years \\
AOT & $7(41.2)$ & $3(17.6)$ & $7(41.2)$ & 7 years \\
CEOT & $3(60)$ & $1(20)$ & $1(20)$ & NS \\
Total & $87(55.8)$ & $40(25.6)$ & $29(18.6)$ & 33 years \\
\hline
\end{tabular}

NS= Not specified; AOT= Adenomatoid Odontogenic Tumor; CEOT= Calcifying epithelial odontogenic tumor.

\section{DISCUSSION}

Odontogenic tumors (OTs) originate from the tissues of tooth formation and reproduce, to a greater or lesser extent, the inductive relationship between the various parts of the normal tooth germ. They constitute a very diverse group of lesions owing to the different degrees of intertissue interaction and various growth patterns (Tawfik \& Zyada). 
In this study of 156 epithelial odontogenic tumors (EOTs), 134 cases of ameloblastoma (AME) was found corresponding to $85.9 \%, 17$ cases $(10.9 \%)$ of adenomatoid odontogenic tumor (AOT) and only 5 cases (3.2\%) of calcifying epithelial odontogenic tumor (CEOT) (Table II). Analyzing the EOTs, a higher prevalence of AME in our study was found in agreement with many studies (Buchner et al.; Tawfik \& Zyada; Adebayo et al.; Simon et al., 2005; Sriram \& Shetty; Luo \& Li; Ochsenius et al.; Jing et al.; Mosqueda-Taylor et al.). We observed that AOT was also the second more prevalent EOTs in other studies (Buchner et al.; Sriram \& Shetty; Ochsenius et al.; Mosqueda-Taylor et al.). And just few cases of CEOT was verified in our study in agreement of others studies (Buchner et al.; Simon et al., 2005; Luo \& Li; Jing et al.; Okada et al.; Ladeinde et al., 2005). In Asia the countries that AME had the highest prevalence was Sri Lanka $69.8 \%$ (Okada et al.); India $61.6 \%$ (Sriram \& Shetty) and China $40.3 \%$ (Jing et al.). In Africa countries, AME was more prevalent in Nigeria $73 \%$ (Adebayo et al.); Tanzania $80.1 \%$ (Simon et al., 2005) and Egypt $41.5 \%$ (Tawfik \& Zyada). In South America, AME was the first EOT in Brazil with $45.3 \%$ (Fernandes et al., 2005). The AOT had prevalence of $0.1 \%$ in Northern California (USA) (Buchner et al.), $7.1 \%$ in Mexico (Mosqueda-Taylor et al.) (North America), $6.6 \%$ in Chile (Ochsenius et al.), $3.8 \%$ in Brazil (Fernandes et al., 2005) (South America), $1.3 \%$ in Estonia (Tamme et al.) (Europe), $2.8 \%$ in Nigeria (Adebayo et al.), $3.7 \%$ in Egypt (Tawfik \& Zyada), $0.9 \%$ in Tanzania (Simon et al., 2005) (Africa), $12.4 \%$ in India (Tawfik \& Zyada), $9.3 \%$ in SriLanka (Okada et al.), $4.1 \%$ in China (Jing et al.) (Asia). And CEOT had prevalence of $0.5 \%$ in Northern California (USA) (Buchner et al.), $0.6 \%$ in Chile (Ochsenius et al.), $0.6 \%$ in China (Jing et al.), $0.8 \%$ in Mexico (Mosqueda-Taylor et al.), $1.2 \%$ in Brazil (Fernandes et al., 2005), $1.3 \%$ in Sri-Lanka (Okada et al.), $1.3 \%$ in Estonia (Tamme et al.), $1.7 \%$ in Tanzania (Simon et al., 2005), $2.4 \%$ in India (Sriram \& Shetty), $2.5 \%$ in Nigeria (Adebayo et al.) and $3.7 \%$ in Egypt (Tawfik \& Zyada).

Gender analysis showed a female predilection for AME and AOT except CEOT (Table I) in agreement with study of Fernandes et al. that found a female predilection in AMEs and a male predilection in AOT, except CEOT that no predilection was found. However, Tawfik \& Zyada found in AMEs a male predilection with $67.6 \%$, a female predilection for AOT with $66.6 \%$ and a male predilection in $100 \%$ of cases of CEOT. Jing et al. found a male predilection in AME, female predilection for AOT and no sex predilection in CEOT.
Table I shows the age range of EOT. The mean age of this population was 38 years, with a wide range (11-80 years). Age distribution of all EOTs showed a peak occurence in the second and third decade, with $30.12 \%$ of the cases occurring in this period. Ameloblastoma (AME), the most common tumor in this study, showed a peak occurrence in the second and third decade, with $33.58 \%$ of the cases. AOT and CEOT showed a peak occurrence in the first and forth decade, with $81.2 \%$ and $60 \%$ of cases, respectively. In study of Sriram \& Shetty, they found a peak occurrence in the third decade for AME, CEOT, and second decade in AOT. Okada et al. found a peak occurrence in the fourth, second and third decades in AMEs, AOTs and CEOTs respectively.

The mandible was clearly the more common site of occurrence for most AMEs with $95.5 \%$ of cases, (Table II) in agreement with Tamme et al., Fernandes et al., Olgac et al., Jing et al., Okada et al., Luo \& Li and Tawfik \& Zyada. The cases of AOT had a predilection for the maxilla in $70.6 \%$ in agreement of studies in Egypt (Tawfik \& Zyada), India (Sriram \& Shetty), Sri-Lanka (Okada et al.), Mexico (MosquedaTaylor et al.), Nigeria (Ladeinde et al.), Libya (El-Gehani et al., 2009), and cases of CEOT were more common in maxilla with $60 \%$ in agreement with studies in Chile (Ochsenius et al.), Turkey (Olgac et al.), Mexico (Mosqueda-Taylor et al.). Others studies in Egypt (Tawfik \& Zyada), China (Jing et al.), Sri-Lanka (Okada et al.), Nigeria (Ladeinde et al.) and Brazil (Fernandes et al), found more occurrence of CEOT in mandible. In general, the EOTs were most commonly encountered in the posterior zone of the mandible, the same in agreement with Fernandes et al., Olgac et al. and Okada et al.

The longest duration of AME, AOT was 33 years and 7 years respectively, CEOT was not specified in this study. Adebayo et al. in Nigeria, found the duration without treatment of 27 years in AME, 4 years in AOT and 34 years in CEOT.

In conclusion, we observed a marked geographic variation in the relative incidences of various epithelial odontogenic tumors (EOTs). This was particularly notable in AMEs and AOTs, with the incidences observed in the present study being similar sometimes different to earlier studies in others parts of the world.

Funding. Ours sources of funding for our research were from Federal University of Rio Grande do Norte, Brazil. 
CAVALCANTE, R. M.; COSTA, M. J. F.; SOUSA E SILVA, N.; DE SOUZA, L. B. \& SANTOS, P. P. A. Tumores odontogénicos epiteliales: análisis de 156 casos en una población brasileña. Int. J. Odontostomat., 10(1):113-118, 2016.

RESUMEN: El objetivo fue determinar la distribución de los tumores odontogénicos epiteliales diagnosticados histológicamente en un período de 41 años en una población brasileña según edad, sexo y la zona afectada y comparar estos datos con estudios anteriores de otros países. Los datos de los tumores odontogénicos epiteliales diagnosticados fueron obtenidos de los archivos del Laboratorio de Patología Oral de la Universidad Federal de Rio Grande do Norte, Natal, $\mathrm{RN}$, Brasil, e introducidos en un formulario estandarizado para comparaciones futuras. Las características clínicas obtenidas a partir de los registros de los pacientes y los portaobjetos de microscopio fueron revisados de acuerdo a la clasificación de la Organización Mundial de la Salud 1992. Se informó de un total de 156 tumores epiteliales odontogénicas. De estos, todos eran benignos. Ameloblastoma fue el tipo más frecuente $(85,9 \%)$, seguido por el tumor odontogénico adenomatoide $(10,9 \%)$ y el tumor odontogénico epitelial calcificante (3,2 \%). La edad media de los pacientes fue de 38 años, con un rango amplio (11-80 años). La región posterior de la mandíbula era el sitio anatómico más afectado por esta enfermedad, y no se encontraron diferencias significativas entre sexos en el diagnóstico de los tumores odontogénicos. Se encontró una marcada variación geográfica en las incidencias relativas de diversos tumores odontogénicos epiteliales. Fue particularmente notable en ameloblastomas y tumores odontogénicos adenomatoide, con las incidencias observadas en este estudio siendo a veces similares, y a veces diferentes de los estudios anteriores en otras partes del mundo.

PALABRAS CLAVE: tumor odontogénico, ameloblastoma, tumor odontogénico adenomatoide, tumor odontogénico epitelial calcificante.

\section{REFERENCES}

Adebayo, E. T.; Ajike, S. O. \& Adekeye, E. O. A review of 318 odontogenic tumors in Kaduna, Nigeria. J. Oral Maxillofac. Surg., 63(6):811-9, 2005.

Buchner, A.; Merrell, P. W. \& Carpenter, W. M. Relative frequency of central odontogenic tumors: a study of 1,088 cases from Northern California and comparison to studies from other parts of the world. J. Oral Maxillofac. Surg., 64(9):1343-52, 2006.

El-Gehani, R.; Orafi, M.; Elarbi, M. \& Subhashraj, K. Benign tumours of orofacial region at Benghazi, Libya: a study of 405 cases. J. Craniomaxillofac. Surg., 37(7):370-5, 2009.

Fernandes, A. M.; Duarte, E. C.; Pimenta, F. J.; Souza L. N.; Santos, V. R.; Mesquita, R. A. \& de Aguiar, M. C. Odontogenic tumors: a study of 340 cases in a Brazilian population. J. Oral Pathol. Med., 34(10):583-7, 2005.

Jing, W.; Xuan, M.; Lin, Y.; Wu, L.; Liu, L.; Zheng, X.; Tang, W.; Qiao, J. \& Tian, W. Odontogenic tumours: a retrospective study of 1642 cases in a Chinese population. Int. J. Oral Maxillofac. Surg., 36(1):20-5, 2007.

Ladeinde, A. L.; Ajayi, O. F.; Ogunlewe, M. O.; Adeyemo, W. L.; Arotiba, G. T.; Bamgbose, B. O. \& Akinwande, J. A. Odontogenic tumors: a review of 319 cases in a Nigerian teaching hospital. Oral Surg. Oral Med. Oral Pathol. Oral Radiol. Endod., 99(2):191-5, 2005.

Luo, H. Y. \& Li, T. J. Odontogenic tumors: a study of 1309 cases in a Chinese population. Oral Oncol., 45(8):706-11, 2009.
Mosqueda-Taylor, A.; Ledesma-Montes, C.; Caballero Sandoval, S.; Portilla-Robertson, J.; Ruiz-Godoy Rivera, L. M. \& Meneses-Garcia, A. Odontogenic tumors in Mexico: a collaborative retrospective study of 349 cases. Oral Surg. Oral Med. Oral Pathol. Oral Radiol. Endod., 84(6):672-5, 1997.

Ochsenius, G.; Ortega, A.; Godoy, L.; Peñafiel, C. \& Escobar, E. Odontogenic tumors in Chile: a study of 362 cases. J. Oral Pathol. Med., 31(7):415-20, 2002.

Ogunsalu, C. O. Odontogenic tumours from two centres in Jamaica. A 15-year review. West Indian Med. J., 52(4):285-9, 2003.

Okada, H.; Yamamoto, H. \& Tilakaratne, W. M. Odontogenic tumors in Sri Lanka: analysis of 226 cases. J. Oral Maxillofac. Surg., 65(5):875-82, 2007.

Olgac, V.; Koseoglu, B. G. \& Aksakalli, N. Odontogenic tumours in Istanbul: 527 cases. Br. J. Oral Maxillofac. Surg., 44(5):386-8, 2006.

Simon, E. N.; Merkx, M. A.; Vuhahula, E.; Ngassapa, D. \& Stoelinga, P. J. A 4-year prospective study on epidemiology and clinicopathological presentation of odontogenic tumors in Tanzania. Oral Surg. Oral Med. Oral Pathol. Oral Radiol. Endod., 99(5):598-602, 2005.

Simon, E. N.; Stoelinga, P. J.; Vuhahula, E. \& Ngassapa, D. Odontogenic tumours and tumour-like lesions in Tanzania. East Afr. Med. J., 79(1):3-7, 2002. 
CAVALCANTE, R. M.; COSTA, M. J. F.; SOUSA E SILVA, N.; DE SOUZA, L. B. \& SANTOS, P. P. A. Epithelial odontogenic tumors: analysis of 156 cases in a Brazilian population. Int. J. Odontostomat., 10(1):113-118, 2016.

Sriram, G. \& Shetty, R. P. Odontogenic tumors: a study of 250 cases in an Indian teaching hospital. Oral Surg. Oral Med. Oral Pathol. Oral Radiol. Endod., 105(6):e14-21, 2008.

Tamme, T.; Soots, M.; Kulla, A.; Karu, K.; Hanstein, S. M.; Sokk, A.; Jõeste, E. \& Leibur, E. Odontogenic tumours, a collaborative retrospective study of 75 cases covering more than 25 years from Estonia. J. Craniomaxillofac. Surg., 32(3):161-5, 2004.

Tawfik, M. A. \& Zyada, M. M. Odontogenic tumors in Dakahlia, Egypt: analysis of 82 cases. Oral Surg. Oral Med. Oral Pathol. Oral Radiol. Endod., 109(2):e67-73, 2010.
Correspondence to:

Prof. Dr. Pedro Paulo de Andrade Santos

Adjunto II - Cirurgião Dentista - Patologista / Protesista

Coordenador de Ensino do Curso de Odontologia

UFCG - Universidade Federal de Campina Grande

Health Center and Rural Tecnology - CSTR

Patos, PB

BRAZIL

Email: ppdasantos@gmail.com

Received: 16-09-2015

Accepted: 02-02-2016 